\title{
Prevention of Human Papillomavirus Infection. Beyond Cervical Cancer: A Brief Review
}

\author{
Prevenção da Infeção pelo Vírus do Papiloma Humano. \\ Para Além do Cancro do Colo do Útero: Uma Breve \\ Revisão
}

Rita MEDEIROS $\square^{1}$, Susan VAZ², Teresa REBELO ${ }^{1,2}$, Margarida FIGUEIREDO-DIAS ${ }^{1,2}$

Acta Med Port 2020 Mar;33(3):198-201 • https://doi.org/10.20344/amp.12259

ABSTRACT

Introduction: Human papillomavirus is responsible for almost all cases of cervical cancer, an important portion of anogenital and oropharyngeal invasive and preinvasive lesions, as well as genital warts (condyloma acuminatum) and recurrent respiratory papillomatosis. Currently, three prophylactic vaccines against high-risk Human papillomavirus are commercialized in many countries worldwide.

Methods: To this non-systematic review the authors searched in MEDLINE/PubMed for systematic reviews, meta-analysis and randomized controlled trials, published in the last six years, using the terms "HPV", "non-cervical cancer" and "vaccine". Non-cervical cancers caused by human papillomavirus are less common lesions. However, its incidence has been increasing, while cervical cancer has declined, due mainly to highly effective screening programs. There are no formal screening programs for non-cervical cancers, so universal vaccination could have an important impact. The preventive effect of the vaccine is mainly studied and established in relation to cervical cancer, although it has also been demonstrated in the development of vulvar and vaginal lesions. To date, the efficacy in preventing anal and oropharyngeal diseases related with human papillomavirus is uncertain due to scarce supporting data and low vaccination coverage in men. The prevalence of injuries and subsequent absolute benefit of vaccination is lower in men, but it provides an additional benefit to the herd immunity achieved with the vaccination of women.

Conclusion: The total fraction of malignant and pre-malignant lesions attributed to Human papillomavirus genotypes contained in the nonavalent vaccine is significant in both women and men, which turns this vaccine into a great asset in terms of Public Health.

Keywords: Papillomavirus Infections; Papillomavirus Vaccines; Uterine Cervical Neoplasms

\section{RESUMO}

Introdução: O vírus do papiloma humano é responsável por quase todos os casos de cancro do colo do útero, de uma importante fração de lesões anogenitais e orofaríngeas pré-invasivas e invasivas bem como de condilomas genitais e da papilomatose respiratória recorrente. Atualmente existem três vacinas profiláticas contra o vírus do papiloma humano de alto risco comercializadas em vários países do mundo.

Métodos: Para esta revisão não-sistemática, os autores pesquisaram na MEDLINE/PubMed revisões sistemáticas, metanálises e ensaios clínicos randomizados, publicados nos últimos seis anos, utilizando os termos "HPV", "cancro não cervical" e "vacina". Os cancros não cervicais causados pelo vírus do papiloma humano são lesões menos comuns. Contudo, a sua incidência tem aumentado, a par de uma diminuição do cancro do colo do útero, devido principalmente à implementação de programas de rastreio altamente eficazes. Uma vez que não existem programas oficiais de rastreio para cancros não cervicais, a vacinação universal pode ter um impacto importante. O efeito preventivo da vacina é principalmente estudado e estabelecido em relação ao cancro do colo do útero, embora também tenha sido demonstrado no desenvolvimento de lesões vulvares e vaginais. Até ao momento, a eficácia na prevenção de doenças anais e orofaríngeas relacionadas com o vírus do papiloma humano é incerta, devido à escassez de dados na literatura e baixa cobertura de vacinação em homens. A prevalência de lesões e o consequente benefício absoluto da vacinação é inferior nos homens, porém proporciona um benefício adicional à imunidade de grupo alcançada com a vacinação de mulheres.

Conclusão: A fração total de lesões malignas e pré-malignas atribuídas aos genótipos de vírus do papiloma humano contidos na vacina nonavalente é significativa tanto em mulheres quanto em homens, o que confere a essa vacina um grande potencial em termos de Saúde Pública.

Palavras-chave: Infecções por Papillomavirus; Neoplasias do Colo do Útero; Vacinas contra Papillomavirus

\section{INTRODUCTION}

Human papillomavirus (HPV) is a sexually transmitted double-stranded DNA virus responsible for the development of anogenital (cervical, vaginal, vulvar, penile and anal) and oropharyngeal diseases in both women and men. The International Agency for Research on Cancer (IARC) considers it a human carcinogen and classifies HPV 16, 18, $31,33,35,39,45,51,52,56,58,59$ and 66 as high-risk (HPV-hr) and HPV 6, 11, 42, 43, 44, 54, 61, 70 , 72, 81 as low risk (HPV-Ir) types. Some genotypes have an uncertain oncogenic potential. High-risk types 16 and 18 account for almost $70 \%$ of all cervical cancers, as well as about $90 \%$ of the anal cancers and a variable fraction of vulvar, vaginal, penile and oropharyngeal cancers. HPV genotypes 31,33 , 45,52 and 58 are the etiological agent for more than $20 \%$ of cervical cancers. Low-risk genotypes 6 and 11 mainly cause cervical, vulvar and vaginal low-grade lesions, and

1. Department of Gynaecology. Hospital and University Centre of Coimbra. Coimbra. Portugal.

2. Department of Gynaecology. Faculty of Medicine. University of Coimbra. Coimbra. Portugal.

$\triangle$ Autor correspondente: Rita Medeiros. rita.adriana.medeiros@gmail.com

Recebido: 24 de abril de 2019 - Aceite: 17 de julho de 2019 | Copyright @ Ordem dos Médicos 2020 
are responsible for $90 \%$ of the anogenital warts or condyloma acuminatum. ${ }^{1-3}$

Vaccination represents one of the most cost-effective public health measures. The development of the prophylactic vaccine against HPV, with the aim of preventing the initial infection and subsequent neoplastic transformation, has generated some controversy. Therapeutic vaccines capable of inducing the regression of existing lesions are under development.

Currently, three different vaccines are commercialized, varying in the number of HPV genotypes contained. All vaccines protect against HPV types 16 and 18. The quadrivalent vaccine also targets types 6 and 11 . The nonavalent vaccine, available in Europe since 2015, in addition to the genotypes present in the quadrivalent vaccine, also covers types $31,33,45,52$, and 58 , predicting $90 \%$ efficacy in reducing the overall incidence of cancers associated with HPV infection. In Portugal, this vaccine has been part of the National Immunisation Schedule since 2008. The nonavalent vaccine in the two-dose scheme replaced the quadrivalent vaccine in January 2017, and has been covering girls aged 10 years. ${ }^{2-6}$ Vaccination in males is recommended by several national and international scientific societies, and its introduction into the immunisation schedule is currently being discussed in Portugal.

The objective of this article is to review the incidence of non-cervical lesions attributed to HPV genotypes contained in the nonavalent vaccine, and to assess its potential impact in terms of Public Health.

\section{METHODS}

A literature search was conducted in the PubMed database between 2013 and 2019 in order to identify papers regarding non-cervical HPV lesions and vaccine. The search was narrowed to articles written in English and Portuguese and the MeSH terms used included: "HPV", "non-cervical cancer" and "vaccine". Studies were included in this review if they were systematic reviews, meta-analysis or randomized controlled trials and were selected on the basis of its the relevance.

\section{Beyond cervical cancer}

Although $90 \%$ of HPV infections are asymptomatic and tend to regress spontaneously within two years, some persist and eventually evolve to genital and/or oropharyngeal neoplasia. A European multicentre study covering 32 countries presented the estimated annual number of new cases of lesions attributable to HPV genotypes covered by the nonavalent vaccine in men and women, updated for the population of $2015 .^{3}$ Within the total number of new cases (53013) of cancer attributable to all HPV types occurring annually in Europe, $90 \%$ are attributed to those present in the nonavalent vaccine ( $81 \%$ occur in women and $19 \%$ in men).

Cervical cancer represents the highest percentage (58.7\%), followed by head and neck (12.8\%), anal $(11.6 \%)$, vulvar $(2.8 \%)$, vaginal $(2.6 \%)$ and penile $(2.1 \%) .{ }^{3}$ According to the CLEOPATRE II study, it is estimated that the seven high-risk genotypes contained in the nonavalent vaccine are responsible for $92.5 \%$ of HPV positive cervical cancers in the Portuguese population. ${ }^{7}$

\section{Head and neck cancer}

HPV infection is known as a risk factor for the development of head and neck squamous cell carcinoma (HNSCC) and its incidence has increased. The risk indicators for highrisk HPV infection are male gender, Caucasian race, age 40 - 59 years, multiple lifetime sex partners and orogenital and oro-anal sex. ${ }^{8}$ Oropharyngeal cancer is a subtype of $\mathrm{HN}$ SCC, estimated to be associated with HPV infection in $70 \%$ of the cases, with higher prevalence in men, Caucasians, aged under 60 , healthier individuals with no or little tobacco exposure and higher socioeconomic status. ${ }^{9}$ It is estimated that $75 \%-100 \%$ of the HPV related cases are attributed to the genotypes present in the nonavalent vaccine, with HPV16 being responsible for $50 \%-92 \%$ of cases. ${ }^{3}$ There is a direct relationship between the early onset of active sexual activity and the high number of partners, similar to what is observed in cervical cancer. ${ }^{10}$ On the other hand, in relation to oral squamous cell carcinoma, tobacco and alcohol still are the major risk factors, responsible for more than $75 \%$ of cases, with only a small subset of less than $10 \%$ being associated with high-risk HPV. ${ }^{8,9}$

\section{Anal cancer}

Anal cancer is relatively rare, but recent studies show an increase in incidence in some developed countries, which may be associated with changes in sexual behaviour, estimated to be related with HPV infection in nearly $90 \%$ of the cases. ${ }^{11}$ Men who have sex with men, particularly if infected by the human immunodeficiency virus (HIV), represent a high-risk group, as well as HIV-infected women. Its natural history resembles that of cervical cancer: both share identical risk factors and transmission mechanisms and emerge from the same type of cells that occur in the transformation zone, that is, between stratified squamous and columnar epithelium. HPV16 is the most frequently implicated genotype, followed by HPV18, representing in total $84.3 \%$ of HPV positive cases. ${ }^{12}$ HPV16 positivity increases with lesion severity in both HIV negative and positive individuals. However, the fraction of anal cancer attributable to HPV16 is smaller in the HIV-positive population, as this virus influences the natural history of HPV. ${ }^{11}$

\section{Vulvar and vaginal cancer}

Vulvar and vaginal cancer are rare neoplasias, being associated with HPV infection in a variable fraction of cases, estimated as $29 \%-43 \%$ and $70 \%$, respectively. ${ }^{13}$ Considering the subgroup of HPV-related cases, it is presumed that $94.3 \%$ of vulvar cancers and $87.1 \%$ of vaginal cancers are attributed to the genotypes present in the nonavalent vaccine. ${ }^{3}$ Unlike HPV-negative cancers, virusassociated lesions tend to occur at a younger age, exhibit basaloid instead of keratinizing characteristics, lack p53 mutations and are associated with sexual risk factors. 
These characteristics are present both in cases of vulvar and vaginal cancers, although vaginal lesions are more frequently associated with HPV infection. ${ }^{14}$

\section{Penile cancer}

Penile cancer is a rare condition globally, yet in some areas of Africa, South America and Asia it represents about $10 \%$ of all cancers in men. ${ }^{1}$ Similarly to female external genital neoplasia, it is not always associated with HPV infection, with genotypes 16 and 18 being responsible for $35 \%$ to $40 \%$ of cases of penile cancer in general and $70 \%$ to $80 \%$ of those related with HPV. Alike vulvar and vaginal cancer, cases of penile cancer associated with the virus tend to occur at a younger age, exhibit basaloid characteristics, lack p53 mutations and are associated with sexual risk factors. ${ }^{14}$ Among cases of penile cancer, it is estimated that the fraction attributable to the genotypes contained in the nonavalent vaccine is $90.7 \% .^{3}$

\section{Recurrent respiratory papillomatosis}

HPV infection has been considered a sexually transmitted disease, but there is increasing evidence pointing to the existence of other transmission routes. Vertical transmission occurs more frequently during vaginal delivery through contact of the fetus with infected maternal cells or during a caesarean section after premature rupture of membranes; ascendant infections have also been described..$^{15}$ Recurrent respiratory papillomatosis represents the most frequent benign laryngeal tumor in children, with $90 \%$ to $95 \%$ of the cases being caused by HPV genotypes 6 and 11. Although it is a benign condition, it can lead to obstructive symptoms, causing significant morbidity. It also has a potential for malignant transformation, particularly to squamous cell carcinoma about $1 \%$ in children and $3 \%$ to $7 \%$ of adults. ${ }^{16}$

\section{Vaccination in men}

Although the natural history and prevalence of HPV infection in men is difficult to assess due to the high rate of silent infections, it is estimated that the prevalence is higher than $50 \%$. Most recent studies report that vaccination of young men seems to cause a reduced direct benefit in the incidence of the disease due to the group immunity achieved with the vaccination of girls. However, this immunity entails a scarce benefit in the era of globalization, due to the circulation between countries and areas with low vaccination coverage rates. On the other hand, even if vaccination coverage in girls was sufficiently high, this would be non-existent in men who have sex with men, who present particularly high rates of HPV-associated lesions. ${ }^{17}$ It is estimated that vaccination in boys may prevent about $94 \%$ of the head and neck cancers attributed to HPV infection and $90 \%$ of penile cancers. ${ }^{3}$

\section{REFERENCES}

1. Bruni L, Albero G, Serrano B, Mena M, Gómez D, Muñoz J, et al. ICO/ IARC Information Centre on HPV and Cancer (HPV Information Centre). Human Papillomavirus and Related Diseases in the World. Summary

\section{Vaccination challenges}

One of the main obstacles to vaccination is the cost associated with its implementation in an immunisation schedule, and this limitation is greater in countries where the financial burden is not borne by the patient. However, several studies have shown that the strategy is cost-effective, considering the economic impact of diseases caused by the virus. The efficacy of the vaccine also depends on access and attitudes towards it, with lower coverage rates being due to cultural beliefs and stigmatization of HPV as a sexually transmitted infection, with a tendency to delay vaccination until the teenager is sexually active. Similarly, there is a tendency to minimize the impact of the infection, associating it only with the development of cervical cancer, and therefore overlooking the need to extend the recommendation of vaccination to males. However, as mentioned above, group immunity achieved with the vaccination of girls carries a reduced benefit in the era of globalization, being non-existent in particularly vulnerable groups, as is the case of men who have sex with men.

At this point, health professionals play an essential role in transmitting information and awareness about HPV infection and its prevention.

\section{CONCLUSION}

HPV is a sexually transmitted pathogen responsible for almost all cases of cervical cancer, as well as an important fraction of preinvasive and invasive anogenital and oropharyngeal lesions in both sexes. The total fraction of malignant and pre-malignant lesions attributed to HPV genotypes contained in the nonavalent vaccine is significant in both women and men, which turns this vaccine into a great asset in terms of Public Health.

\section{PROTECTION OF HUMANS AND ANIMALS}

The authors declare that the procedures were followed according to the regulations established by the Clinical Research and Ethics Committee and to the Helsinki Declaration of the World Medical Association.

\section{DATA CONFIDENTIALITY}

The authors declare having followed the protocols in use at their working center regarding patients' data publication. Patient consent obtained.

\section{CONFLICT OF INTEREST}

The authors declare that they have no conflict of interest with regard to this article.

\section{SOURCE OF FUNDING}

The authors declare that they have not received subsidies or scholarships for the elaboration of the article.

Report 17 June 2019. [accessed 2019 Jul 16]. Available from: www. hpvcentre.net/statistics/reports/XMX.pdf.

2. de Oliveira CM, Fregnani JH, Villa LL. HPV vaccine: updates and 
highlights. Acta Cytol. 2019;63:159-68.

3. Hartwig S, Lacau J, Guily S, Dominiak-Felden G, Alemany L, de Sanjosé $\mathrm{S}$. Estimation of the overall burden of cancers, precancerous lesions, and genital warts attributable to 9-valent HPV vaccine types in women and men in Europe. Infect Agent Cancer. 2017;12:19.

4. Trimble CL, Morrow MP, Kraynyak KA, Shen X, Dallas M, Yan J, et al. Safety, efficacy, and immunogenicity of VGX-3100, a therapeutic synthetic DNA vaccine targeting human papillomavirus 16 and 18 E6 and E7 proteins for cervical intraepithelial neoplasia 2/3: a randomised, double-blind, placebo-controlled phase 2 b trial. Lancet. 2015;386:207888.

5. World Health Organization. Human papillomavirus vaccines: WHO position paper. Wkly Epidemiol Rec. 2014;89:465-91

6. Direção Geral da Saúde. Programa Nacional de Vacinação 2017. Norma da DGS. Lisboa: DGS: 2016.

7. Pista A, Freire de Oliveira C, Lopes C, Cunha MJ, Cleopatre Portugal Study Group. Human papillomavirus type distribution in cervical intraepithelial neoplasia grade $2 / 3$ and cervical cancer in Portugal A CLEOPATRE II Study. Int J Gynecol Cancer. 2013;23:500-6.

8. Yakin M, Seo B, Hussaini H, Rich A, Hunter K. Human papillomavirus and oral and oropharyngeal carcinoma: the essentials. Aust Dent J. 2019;64:11-18.

9. Tanaka TI, Alawi F. Human papillomavirus and oropharyngeal cancer. Dent Clin North Am. 2018;62:111-20.

10. Mallen-St Clair J, Alani M, Wang M, Srivastan E. Human papillomavirus in oropharyngeal cancer: the changing face of a disease. Biochim
Biophys Acta. 2016;1866:141-50.

11. Lin C, Franceschi S, Clifford GM. Human papillomavirus types from infection to cancer in the anus, according to sex and HIV status: a systematic review and meta-analysis. Lancet Infect Dis. 2018;18:198206.

12. Alemany L, Saunier M, Alvarado-Cabrero I, Quirós B, Salmeron J, Shin $\mathrm{H}$, et al. Human papillomavirus DNA prevalence and type distribution in anal carcinomas worldwide. Int J Cancer. 2015;136:98-107.

13. de Sanjosé S, Alemany L, Ordi J, Tous S, Alejo M, Bigby S, et al. Worldwide human papillomavirus genotype attribution in over 2000 cases of intraepithelial and invasive lesions of the vulva. Eur $\mathrm{J}$ Cancer. 2013;49:3450-61.

14. Halec G, Alemany L, Quiros B, Clavero O, Höfler D, Alejo M, et al, on behalf of the HPV VVAP Study Group. Biological relevance of human papillomaviruses in vulvar cancer. Mod Pathol. 2017;30:549-62.

15. Trottier H, Mayrand MH, Coutlée F, Monnier P, Laporte L, Niyibizi J, et al. Human papillomavirus (HPV) perinatal transmission and risk of HPV persistence among children: design, methods and preliminary results of the Heritage study. Papillomavirus Res. 2016;2:145-52.

16. Fortes HR, von Ranke FM, Escuissato DL, Araujo Neto CA, Zanetti G, Hochhegger B, et al. Recurrent respiratory papillomatosis: a state-ofthe-art review. Respir Med. 2017;126:116-21.

17. Harder T, Wichmann O, Klug SJ, van der Sande M, Wiese-Posselt M. Efficacy, effectiveness and safety of vaccination against human papillomavirus in males: a systematic review. BMC Med. 2018;16:110. 